Z. klin. Chem. u. klin. Biochem.

9. Jg., S. $334-336$, Juli 1971

\title{
Gel isoelectric focusing of cerebrospinal fluid proteins: a potential diagnostic tool
}

\author{
By P. Delmotte \\ Centre national pour la Śclérose en Plaques, Melsbroek, Belgium
}

1

(Eingegangen am 17. Februar 1971) A method for the separation of the $\gamma$-globulins of cerebrospinal fluid by isoelectric focusing in thin layers of acrylamid gel is presented.
The method is described in detail and some results obtained with fluids from Multiple Sclerosis patients are reported.

Es wird ein Verfahren für die Trennung der $\gamma$-Globuline der Cerebrospinalflüssigkeit durch isoelektrische Fokussierung in dünnen Schichten von Acrylamid beschrieben. Das methodische Vorgehen wird ausführlich beschrieben. Einige Ergebnisse der Liquoruntersuchung von an Multipler Sklerose erkrankten Patienten werden mitgeteilt.

Isoelectric focusing of proteins is now well established as a powerful tool in protein chemistry following its introduction a few years ago $(1,2)$. Unfortunately, this new technique has not yet found practical day to day use in the clinical laboratory. This communication describes a reproducible and easy method for gel isoelectric focusing $(3,4,5)$ : It also contains the preliminary results obtained with cerebrospinal fluid proteins, mostly from multiple sclerosis cases.

\section{Methods}

Apparatus

A plastic foodbox (length $35 \mathrm{~cm}$, width $25 \mathrm{~cm}$, height $15 \mathrm{~cm}$ ) serves as the separation chamber. It contains the refrigeration platform on which rests the glass plate carrying the gel during the separation run. This refrigeration platform is constructed by cementing together a $2 \mathrm{~mm}$ thick aluminium plate (31 by $17 \mathrm{~cm})$, a perspex spacer contour ( $8 \mathrm{~mm}$ thick) and a second perspex plate ( $3 \mathrm{~mm}$ thick). Suitable in- and outlets are provided for the circulation of tap water between the two plates. Carbon rods are held parallel in an adjustable framework permitting slight movement in all directions so as to permit close contact between the rods and the gel surface. The two halves of the framework are isolated from each other by a piece of perspex. The entire electrode assembly rests directly on the gel without damaging it. During separation, the gel between the electrodes is covered with a thin sheet of plastic. In this way no special precautions are necessary to avoid drying out of the gel and very reproducible results are obtained.

\section{Preparation of the plates}

Glass plates ( $3 \mathrm{~mm}$ thick) measuring 14 by $28 \mathrm{~cm}$ are cleaned in strong caustic soda and in chromic acid mixture. They are dried at $120^{\circ}$ just prior to use. One of the plates is strongly siliconised (Siliclad Clay-Adams) and it can be used many times. The two plates (one siliconised) spaced at three sides with a piece of Silastic tubing (Dow-Corning, 602-201), are clamped together with strong paper clips and placed vertically in front of a 10 watt fluorescent lamp.

\section{Gel preparation}

Very low concentrations of gel are recommended in order to avoid, as far as possible, sieving effects, which cause streaking of protein bands. Just prior to use, $2 \mathrm{~g}$ of acrylamide and $125 \mathrm{mg}$ of bis-acrylamide are dissolved in about $30 \mathrm{ml}$ of water in a $50 \mathrm{ml}$ graduated flask. $1 \mathrm{ml}$ of $\mathrm{N}, \mathrm{N}, \mathrm{N}^{\prime} \mathrm{N}^{\prime}$-tetramethylethylendiamine ( $3 \%$ in water, neutralised to $\mathrm{pH} 7$ with $\mathrm{HCl}$ ), and $5 \mathrm{ml}$ of riboflavine $(80 \mathrm{mg} / \mathrm{l})$ are added and the whole brought to $50 \mathrm{ml}$ with water. After brief degassing under strong vacuum, the solution is poured between the two plates with the aid of a $50 \mathrm{ml}$ plastic syringe and a piece of thin polyethylene tubing. Polymerisation is achieved by illuminating for at least $30 \mathrm{~min}$. The paper clips and Silastic tubing are removed and the siliconised glass plate is removed, starting at one corner. The glass plate with the gel attached is soaked for a few hours in at least 21 of distilled water. This washes out all traces of catalyst and unpolymerised arylamide. Otherwise artefacts may be formed with the proteins. The appropriate ampholines are next introduced into the gel by spreading them on top of the gel with the aid of a bent pasteur pipet. Continued spreading under a fan permits penetration of the ampholines in about $15 \mathrm{~min}$. Thereafter the gel plates are put overnight in a humid atmosphere provided by a well sealed plastic box containing a layer of water. This equilibration permits an even distribution of the ampholines throughout the gel.

\section{Ampholines}

In order to have all of the $\gamma$-globulins focused between the midplate sample slot and the cathode end of the plate we use a mixture of different ampholine preparations (final concentration: $1.25 \mathrm{~g}$ / $100 \mathrm{ml}$ ). This mixture ( $\mathrm{pH}$ range $3-10: 2$ vol; $\mathrm{pH}$ range $5-7: 4$ vol; $\mathrm{pH}$ range $7-10: 5$ vol; $\mathrm{pH}$ range $6-8: 3$ vol.), also gives, in this particular case, a better separation of the $\gamma$-globulins than the usual $\mathrm{pH} 3-10$ range alone.

\section{Sample introduction and separation}

Suitable troughs are cut out of the gel at mid-plate with a scalpel. Six slots, 2 by $12 \mathrm{~mm}$, can easily be accomodated on one plate. Protein solutions (mostly $20 \mu \mathrm{l}$ of 4 to $7 \mathrm{~g} / 100 \mathrm{ml}$ ) are put in the troughs which are then filled to the rim with distilled water. The openings are covered with small, thin pieces of glass ( 6 by $20 \mathrm{~mm}$ ), made by cutting microscope cover slips with a diamond glass cutter. The plastic sheet, first soaked in water and briefly dried with filter paper, is lowered onto the gel starting on one of the shorter edges. The carbon rods are also soaked in water, excess fluid wiped off and placed on the surface of the gel. After making the electrical connections, the box is closed and a potential is applied. Tap water is kept running all the time and the maximum energy is never allowed beyond about 1.5 watts. Typical figures for voltage and current for the described ampholine mixture are $200 \mathrm{~V}$ and 3 to $4 \mathrm{~mA}$ at the start and $400 \mathrm{~V}, 1.5 \mathrm{~mA}$ at the end of the 16 hour run. 
Visualisation of the protein bands

At the end of the focusing the proteins are fixed by soaking the plates for 2 hours in a 10 percent solution of trichloracetic acid (the plastic sheet and small glass covers must be removed prior to fixation). Next the plates are washed for a minimum of one hour each in six changes of $3 \%$ trichloracetic acid solution, followed by one hour in $7 \%$ acetic acid solution. This elaborate washing procedure is necessary to remove all traces of ampholines before staining the proteins. We use a 90 min. staining on $0.5 \%$ amido black in $7 \%$ acetic acid. Afterwards the plates are washed in $7 \%$ acetic acid in tap water until the background is completely colorless.

\section{Scamining of the gel}

To trace the absorption pattern of the protein distribution we use direct scanning of the wet gel on the glass plate with a DD2 microdensitometer (Kipp, Delft, Netherlands and Leeds and Northrup recorder).

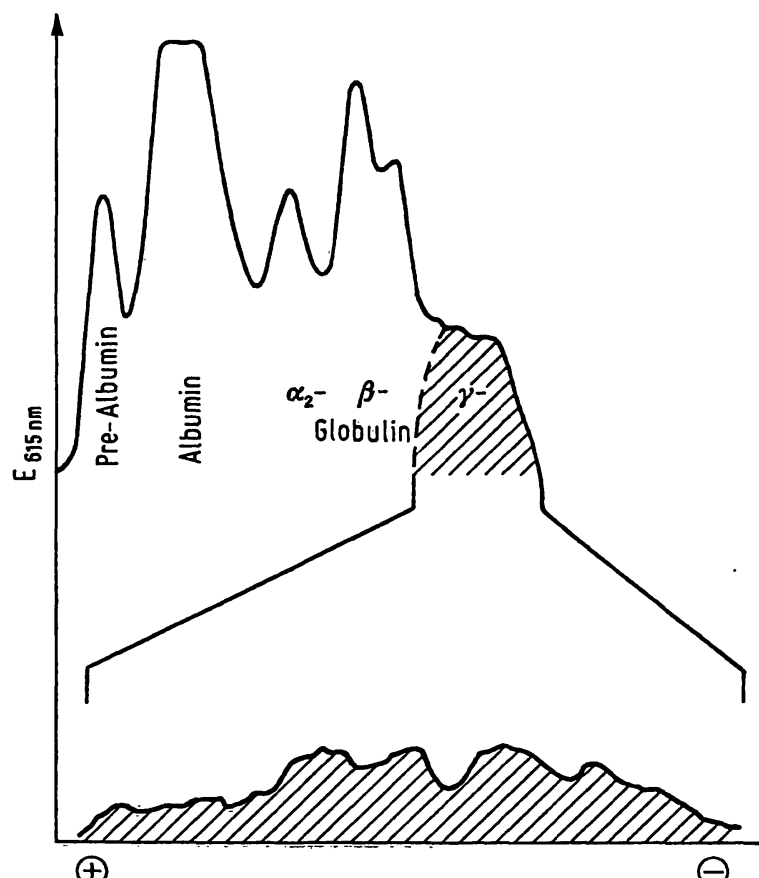

Fig. 1

$\gamma$-Globulin pattern from a normal cerebrospinal fluid (bottom) compared with the ordinary agar electrophoresis pattern (migration direction $\Theta \rightarrow \Theta$ ) of the same fluid (top)

\section{Results}

Application of this method to the comparative study of the serum $\gamma$-globulins of normal individuals and multiple sclerosis patients did not reveal any significant differences.

On the other hand, when it was applied to the $\gamma$-globulins of cerebrospinal fluid, very characteristic patterns were obtained. Figure 1 shows the $\gamma$-globulin pattern from a normal cerebrospinal fluid, compared with the ordinary agar electrophoresis pattern of the same fluid. Normal cerebrospinal fluids produce isoelectric focusing patterns strikingly similar to those obtained with serum (unconcentrated and untreated) under the same conditions. Figure 2 shows the comparison between two such $\gamma$-globulin distribution tracings. Until now we were unable to study cerebrospinal fluids from non-neurological cases, so that in the present work "normal" fluids are those that present a $\gamma$-globulin distribution pattern like that of the serum $\gamma$-globulins. Cerebrospinal fluids from multiple sclerosis patients, however, produce strikingly different tracings. They

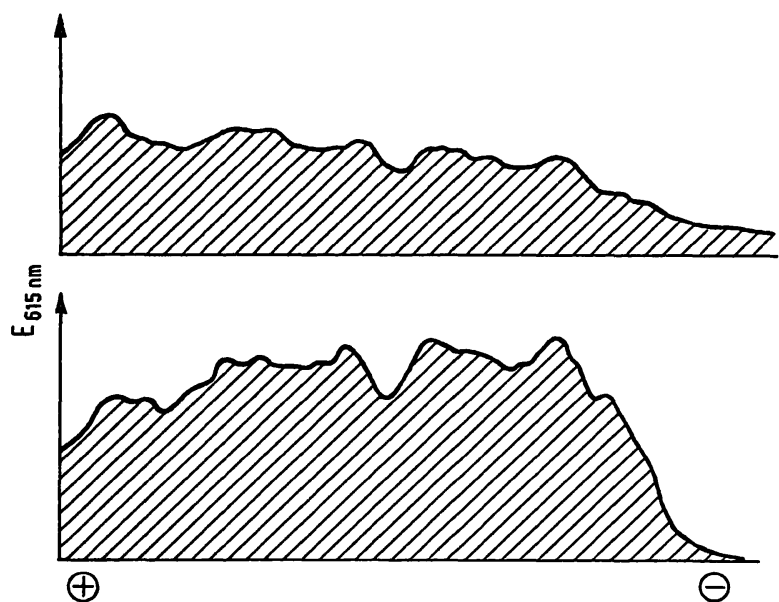

Fig. 2

Comparison between the electrofucusing patterns of $\gamma$-globulins from normal liquorcerebrospinalis (top) and normal serum (bottom)

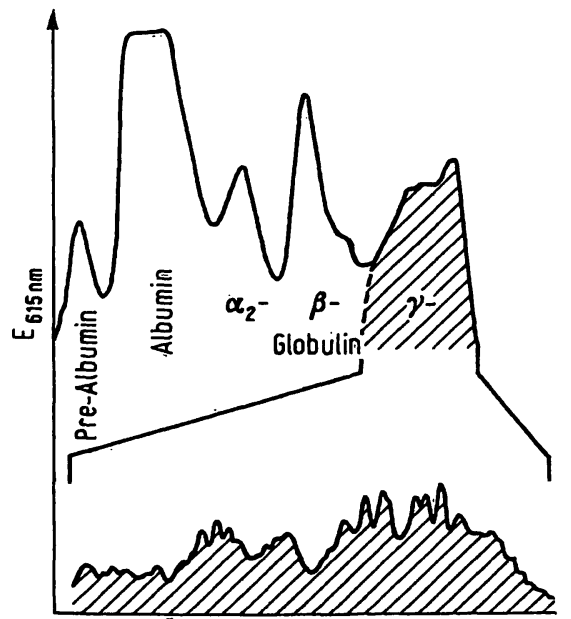

$\oplus$

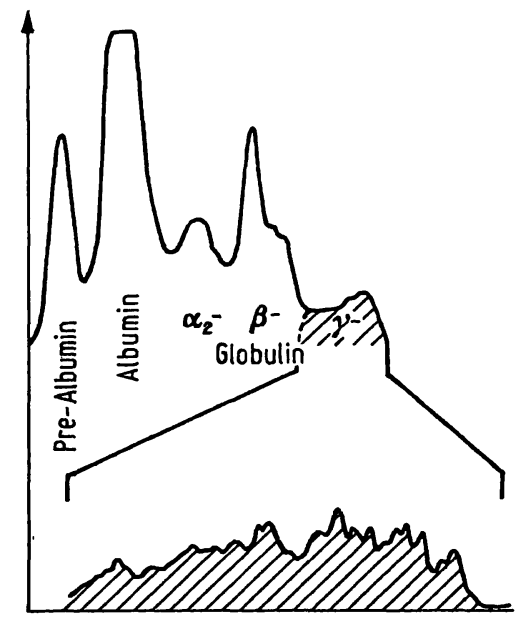

Fig. 3-5

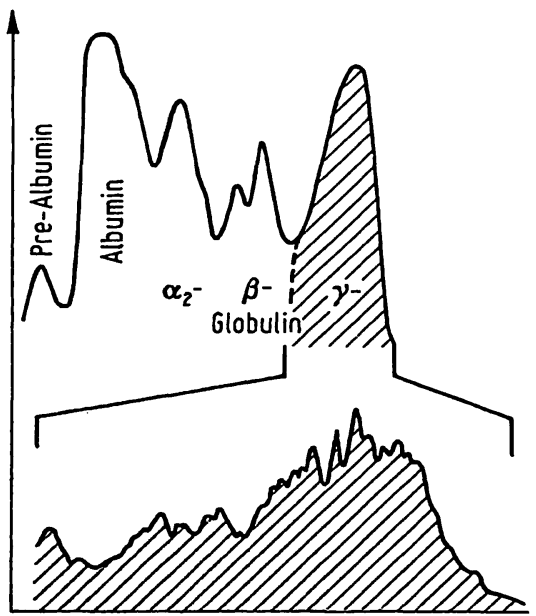

$\Theta$

$\gamma$-Globulin patterns from multiple sclerosis cerebrospinal fluids (bottom) compared with the ordinary agar electrophoresis patterns (migration direction $\Theta \rightarrow \oplus$ ) of the saine fluids (top) 
are characterised by a great number of very sharply defined peaks and a much more pronounced concentration of $\gamma$-globulins with a high isoelectric point. Practically all of the clinically well defined cases of multiple sclerosis have so far produced these characteristic patterns. The number of sharp peaks and their relative importance did however vary quite considerably from case to case. Figures 3, 4 and 5 show some of these $\gamma$-globulin distribution patterns. Based on the limited number of cases studied so far it seems that the more progressive cases of multiple sclerosis do show the greatest number of sharply defined peaks and also the highest concentration of $\gamma$-globulins with alkaline isoelectric points.

It is a well known fact that not all of the clinically confirmed cases of multiple sclerosis do show the characteristic bands in the $\gamma$-globulin region when studied by agar electrophoresis. It appears that even the cere- brospinal fluids of multiple sclerosis patients with practically normal agar electrophoresis results do produce a characteristic $\gamma$-globulin distribution pattern when studied by gel isoelectric focusing. The results of a series of 12 randomly chosen fluids of multiple scle-

- Tab. 1

Comparison of the results obtained by agar electrophoresis and isoelectric focusing. Compared are the findings of 12 clinically confirmed cases of multiple sclerosis

\begin{tabular}{lccc}
\hline & \multicolumn{2}{c}{ Characteristic bands in the $\gamma$-globulin } \\
& \multicolumn{4}{c}{$\begin{array}{c}\text { region } \\
\end{array}$} & positive & doubtful & negative \\
Agar Electrophoresis & 5 & 4 & 3 \\
Isoelectric focusing & 12 & 0 & 0 \\
\hline
\end{tabular}

rosis cases is shown in Table 1 . It thus appears that gel isoelectric focusing may well contribute significantly in this clinically difficult field.

\section{References}

1. Svensson, H., Acta Chem. Scand. 15, 325 (1961). - 2. VesterBerg, O. and H. Svensson, Acta Chem. Scand. 20, 820 (1966). 3. FAwCETr, J.S., FEBS Letters, 1, 81 (1968). - 4. LEABACK, D. H. and A. C. Rutrer, Biochem. Biophys. Res. Commun. 32, 447 (1968). - 5. AWDEH, Z. L., Science Tools, 16, 42 (1969). 